\title{
Family language policy in Russian-Estonian and Russian-Spanish multilingual settings
}

\author{
Olga IVANOVA ${ }^{1}$ and Anastassia ZABRODSKAJA ${ }^{2}$ \\ ${ }^{1}$ University of Salamanca \\ Salamanca, Spain \\ ${ }^{2}$ Tallinn University \\ Tallinn, Estonia
}

\begin{abstract}
This paper primarily focuses on the family language policy of bilingual Russian-Estonian and Russian-Spanish families in relation to the maintenance of Russian as a heritage language. Its main objective is to identify social factors that either help or hinder this process. In doing so, this paper searches for commonalities and specificities of the mainstream attitudes towards Russian as a heritage language in Estonia and Spain, by analysing the sociolinguistic situation of Russian in both countries and by examining the factors conditioning the maintenance of Russian as a heritage language in family settings. Our research is based on an in-depth analysis of a variety of sources, mainly quantitative statistical and demographic data on self-reported language behaviour and language ideologies in mixed families from Estonia $(n=40)$ and Spain $(n=40)$. The main results of our comparative study confirm the general positive attitude towards Russian as a heritage language, but they also highlight an important variability of these attitudes both between countries and within each community. We show that these attitudes directly determine the principles of family language policy, the parents' strategies to transmit Russian as a heritage language, and the level of proficiency in Russian as a heritage language in the second generation. These results allow us to conclude that, as a heritage language, Russian relies on strong attitudinal support in even small communities, like Estonian or Spanish, but also that its confident transmission should rely on external subsidy.
\end{abstract}

Keywords: Russian, heritage language, bilingualism, language management, Estonia, Spain

\section{For citation:}

Ivanova, Olga \& Anastassia Zabrodskaja. 2021. Family language policy in Russian-Estonian and Russian-Spanish multilingual settings. Russian Journal of Linguistics 25 (4). 1047-1070. https://doi.org/10.22363/2687-0088-2021-25-4-1047-1070 


\title{
Семейная языковая политика в русско-эстонской и русско-испанской многоязычной среде Ольга ИВАНОВА ${ }^{1}$, Анастасия ЗАБРОДСКАЯ ${ }^{2}$ \\ ${ }^{1}$ Университет Саламанки \\ Саламанка, Испания \\ ${ }^{2}$ Таллинский университет \\ Таллин, Эстонияя
}

\begin{abstract}
Аннотация
В данной статье основное внимание уделяется языковой политике, которой придерживаются двуязычные русско-эстонские и русско-испанские семьи по отношению к сохранению русского языка как унаследованного. Основная цель статьи - определить социальные факторы, которые либо помогают, либо препятствуют этому процессу. Данная статья рассматривает общие черты и специфику глобальных отношений к русскому языку как унаследованному в Эстонии и Испании на основе анализа социолингвистической ситуации русского языка в обеих странах и исследования факторов, которые способствуют поддержке русского языка как унаследованного в семьях. Это исследование основано на глубоком анализе различных источников, включая количественные статистические и демографические данные о самооценке языкового поведения и языковых идеологий в смешанных семьях Эстонии $(\mathrm{n}=40)$ и Испании $(\mathrm{n}=40)$. Основные результаты этого сравнительного исследования подтверждают общее положительное отношения к русскому языку как унаследованному, но они также подчеркивают его значительную вариативность как между странами так и внутри каждого сообщества. Мы указываем на то, как это отношение напрямую влияет на семейную языковую политику, родительские стратегии в передаче русского языка как унаследованного, а также на уровень владения русским языком как унаследованным во втором поколении. Эти результаты дают нам возможность заключить, что русский язык как унаследованный полагается на значительную эмоциональную поддержку даже в таких маленьких сообществах как эстонская и испанская, а также что для его успешного поддержания необходимы внешние субсидии.
\end{abstract}

Ключевые слова: русский язык, «эритажный» (унаследованный) язык, двуязычие, управление языками, Эстония, Испания

\section{Для цитирования:}

Ivanova O., Zabrodskaja A. Family language policy in Russian-Estonian and Russian-Spanish multilingual settings. Russian Journal of Linguistics. 2021. Vol. 25. № 4. P. 1047-1070. https://doi.org/10.22363/2687-0088-2021-25-4-1047-1070

\section{Introduction}

Since the dissolution of the USSR in 1991, more than seven and a half million people emigrated from the former Soviet republics in search of better social and economic opportunities. A significant number of ex-Soviet expatriates settled in Europe. Germany and Israel - historical destinations for citizens from the former USSR - again became the main centres of attraction during the 1990s, and Southern European countries, such as Italy and Spain, attracted more professional and economic migration from the 2000s on (Denisenko 2020).

As a result, new areas of Russian as a heritage language (RHL) have formed in different parts of the world. Besides the traditional milieux, Russian is becoming 
increasingly common in new settlement sites, where Russophone diaspora opted to maintain Russian because of its role as a lingua franca for Russian-speakers from former Soviet countries (Maximova et al. 2018, Pavlenko 2006, Pencheva 2017), its intense commodification (Muth 2017) and its extension to professional areas, like health-care (Suryanarayan 2017). Presently, the number of Russian-speakers, both native and non-native, living outside Russia is almost equal to speakers living in the homeland (Aref'ev 2014, Ryazanova-Clarke 2014). However, there are still many socio-political settings in Europe where Russian is widely used but where its situation is also shifting, uncertain or unstudied. Divergences among post-Soviet states are sometimes huge (for a global overview, see Pavlenko 2013), and some national situations are still undergoing major sociolinguistic changes. In the Baltic countries, post-Soviet languages policies of the early 1990s shaped a new social modality for the Russophone population: over the course of three decades, Russian changed from being the dominant official to being a foreign language. These thirty years have given Estonia (as well as Latvia and Lithuania) the first generation of residents who learnt Russian as a native (or one of the first) language/s under its official status as foreign.

In addition, Russian is emerging as a diaspora language in some European countries where it has not previously had an important presence but where the number of Russian-speakers has been steadily increasing. Russophones arrive for different reasons, and in some cases, they will to uproot themselves from their original culture. This is frequent among Russophones in Spain, where more than 70,000 Russians (not counting Russophones from other ex-Soviet states) has settled since 2000 in different parts of the country. At present, a large number of Spanish Russophones intermarried with Spaniards and are raising children with RHL.

In this paper, we focus on these two countries - Estonia and Spain - which represent the challenging socio-political cases described above. Our aim is to understand the principles of family language management in intermarriages in these countries and, consequently, to offer an outline of the vitality, functionality and ideological value of Russian in these under-determined sociolinguistic milieu. We define both of them as 'under-determined' for not endorsing the acquisition and use of Russian, but leaving the decision to family agents. In line with previous research (Lanza 2007), we maintain that family language policy, management and attitudes greatly influence the process of heritage language maintenance, reflecting the ideological and social position of parents on their languages (King et al. 2008).

Concerning heritage language transmission, family language policy is closely linked to parental language everyday language management activities (Schwarz 2008). In intermarriages, family language policy plays a very important role in regulating its continuity and even social vitality (Pillai et al. 2014). Making decisions regarding home language policy may become challenging for transnational families, specifically when they have to "choose" which of the languages will fulfil which role within and outside the family setting (Hirsch \& Lee 2018). In this research, based on the classic Spolsky (2012) model of family 
language policy as a conglomerate of ideologies, management and practices, we ask which social factors determine the degree of vitality of RHL in different diaspora settings and why in apparently similar social circumstances the maintenance and transmission of RHL may differ greatly. The sociolinguistic settings we analyze are under-determined: in both Estonia and Spain, Russophones are left to their own devices in deciding whether to maintain RHL with their children. We should emphasise that the situations compared in this study are not chosen randomly. As sociolinguistic settings where the presence of RHL is notable, despite their vast differences, Estonia and Spain share common social and political traits. In this sense, the present study provides a novel contrastive perspective on family language policy in two partially similar and partially dissimilar sociolinguistic settings. Previous information on contrasts between Estonia and Spain can only be found in studies conducted by Laitin (1992) and Branchadell (2011) comparing issues of language normalisation and the policy regarding Russian and Spanish in Estonia and Catalonia, respectively. To our knowledge, no previous research has been conducted regarding the sociolinguistic situation of RHL in these two countries, though such a contrastive study could provide interesting data on the vitality of RHL as shown in related works, for example Karpava, Ringblom \& Zabrodskaja $(2018,2019,2020,2021)$. As a result, the present research will contribute to the growing but still scarce research on RHL, especially in Europe.

\section{Russian as a heritage language in Estonia and Spain: similarities and differences}

The presence of RHL in Estonia and Spain is defined by several common characteristics that allow for inter-country comparison. However, there are also some sociolinguistic differences, which allow for interesting contrasts of the roles and values of RHL in small communities.

Let us start by defining Estonia and Spain as geopolitical milieus for RHL development. In both, there is an intra-continental relationship with the country of origin of Russian-speaking migrants, which is favourable for maintaining close and frequent links with the motherland. In the case of Estonia, there is a direct border with Russia that connects Estonian and Russian languages and cultures, and this eases the transmission of linguistic and cultural heritage values (see Karpava et al. 2020). However, in Spain, Russian-speaking host countries (if we assume that some post-Soviet nationals are Russian-speaking and bilingual in their national language and Russian) are more than 3000 kilometres away, which prevents continuous and direct contact. This fact influences the way in which Russian-speaking communities in both countries reinforce ties with the Russian language through homeland trips and direct contact with Russian-speaking communities in nearby countries (e.g., Karpava et al. 2020). Previous studies (see, for example, García 2003, for a review) highlighted the possible impact of geographical distance from the homeland on heritage language transmission.

In Spain, trips to the homeland are costly and time-consuming in comparison with Estonia, and only well-to-do families can afford annual home visits. The 
Russian language is definitely a minority language in both Estonia and Spain, although this subordinate role differs in terms of the relationship with the official language. In Estonia, Russian does not have a classic minority-majority relationship with Estonian: its historical presence in Estonia during the second part of the 20th century as a language of interethnic communication determined that even today there are many L1 speakers of Russian despite the one-official-language policy. In Spain, Russian is just one of the immigrant languages, on a par with Arabic, Romanian, Ukrainian, Polish and Portuguese. In this sense, the relationship between Russian and Spanish in Spain follows a classic model of minority-majority languages. In any case, Russian in Estonia and Spain has the same status as a foreign language.

As for language legislation, Estonia and Spain have both similar and different ways of treating immigrant languages. In both countries, there is only one state language: Estonian and Spanish respectively, though the Spanish Constitution recognises two official languages in bilingual regions of the country. English is an L2 language in both Estonia and Spain, although it is used in different ways. Many Estonians, especially younger ones, speak English fluently; though in Spain knowing English is almost fully limited to the youngest generation. This is crucial for understanding family language policies in intermarriages: in the case of Spain, few mixed families can rely on English as a family lingua franca and this strengthens the position of Spanish as the main means of communication.

\subsection{Russian in Estonia: historical and sociolinguistic background}

Since the break-up of the USSR in 1991, there have been multiple sociolinguistic changes related to the de facto and de jure status of the Russian language. Estonian was declared the only official language again (as it was during the first period of independence, in 1918-1940), and the goal was set to promote bilingualism amongst the Russian-speaking communities living in Estonia. For this reason, the post-Soviet urban socio-cultural-linguistic environment has attracted scholarly interest "as a contested linguistic space, where emotional exchanges over language-related issues are fodder for the daily news" (Pavlenko 2008: 275). However, as large-scale survey research showed (Ehala \& Zabrodskaja 2013), the picture of a strict division of the Estonian society along ethnolinguistic lines is an oversimplification. Russian-speakers do not form a single unitary category with a uniform value system and attitudes but show different tendencies about culture and language maintenance or assimilation. Thus, the integration of the Russianspeaking population in Estonia varies from full integration to a complete lack of integration, and the sociolinguistic background itself is quite uneven.

There is a great deal of sociolinguistic research on the Russian-speakers of Estonia (Kemppainen et al. 2004, Verschik 2005, Adamson \& Tshuikina 2015, Karpava et al. 2018, to mention just a few). Much of what is known about them is that Russian-speakers are in a socially subordinate position as speakers of a minority language in Estonia. Estonian Russian-speakers cannot be considered a 
typical minority group due to socio-historical factors. But this is not a typical postcolonial setting either: their language has not retained the powerful position that, for example, French and English have retained in much of present-day Africa or India.

Russian was the dominant language of a number of different ethnicities in the territory of the Soviet Union who settled in Estonia during the Soviet period. As their common identity is constructed mainly by means of the Russian language, these groups might be called Russian-speaking communities without distinguishing their different ethnic backgrounds. Most of them had to adapt to the Estonian postindependence language policy, which requires certified proficiency in the Estonian language in order to be hired for certain jobs and to participate fully in the sociopolitical life of the country, which has systematically led to the formation of individual bilingualism in the Russian community.

As of January 2021, the population of Russians in Estonia was estimated at 320,000 , which is $24 \%$ of the total population (1.3 million people). According to the Population and Housing Census (2011), there are representatives of 192 ethnic nationalities living in Estonia and 157 languages are spoken as mother tongues. The same census also showed that the share of Russian-speakers is $29.6 \%$. This means that there are other ethnicities that use Russian as their first language. This is why it would be more accurate to use the term 'Russian-speaker,' rather than 'Russian.' As Laitin (1998) noted, the "Russian-speaking population" is a sub-identity of Russians, not a new category of identity in post-Soviet Estonia.

The sizeable Russian-speaking population of Estonia lives very compactly: only $20 \%$ live in majority Estonian-speaking areas. Almost half of the Russianspeaking population lives in Tallinn and a third in Ida-Viru County, a region that is economically weaker than the country as a whole. Here, the density of the Russianspeaking population is extremely high.

Estonia offers Russian-language instruction in basic schools; secondary education must be at least $60 \%$ in the Estonian language. The local Russianlanguage cultural life and media are fairly poor in comparison with Russia's. A strong factor is that families, whether only Russian-speaking or Russian-Estonian bilingual, maintain close (family, cultural and economic) ties with Russia, and this impacts the ethnic, cultural and linguistic identities of Russian-speaking family members and children.

Russian-speaking people live in a bilingual society in Estonia, where Estonian is the dominant and prestigious language. In fact, to get Estonian citizenship, among other requirements, one must pass an Estonian language proficiency examination and an examination of knowledge of the Constitution of the Republic of Estonia and the Citizenship Act. This influences parental decisions about educational trajectories, especially when considering that the Estonian language proficiency examination is not required if a person has acquired basic, secondary or higher education in Estonian.

Estonia is not a destination for significant transnational migration currently: still, globalisation has increased the importance of English for the Estonian- 
speaking and Russian-speaking populations. In general, in Estonian society Russian is still associated with Soviet occupation (Best 2013), although at the beginning of the $21^{\text {st }}$ century Russian was still the preferred language for interethnic contacts in Estonia and was the main language of information in the sphere of Russianspeakers, who built their identities with Russian in mind (Siiner 2006: 162).

\subsection{Russian in Spain: a recent story}

Russian arrived in Spain at the end of the $20^{\text {th }}$ century because of massive migration from ex-Soviet countries to the West. During the 1960s and 1970s, Spain was a country of emigrants (Babiano \& Farré 2002), but from the late 1980s on Spain began receiving immigrants (Corkill 2001). Currently, Spain is one of the most important magnets for CIS immigrants in Europe (Denisenko 2020: 118).

Unlike the Baltic countries, Mediterranean states attracted post-Soviet immigration for three main reasons: an easy-to-merge-into labour market, even after the financial crisis of 2008; a favourable climate; and a social environment usually open and friendly to foreigners. Even in 2020, despite the world health crisis, many people from the CIS still settled in Spain. Among the top host states for immigrants, Mediterranean countries are not only attractive for their climate and favourable labour markets but also for their relaxed immigration policies, initiated in the 1990s (Leifsen \& Tymczuk 2012) and characterised by frequent regularisation waves (Alted 2006), as well as for ease of integration into the openminded Spanish society.

In Spain, immigrants from Russia now number approximately 78,000, which is 75,500 more than in 1998 (official data provided by the Spanish National Institute for Statistics), i.e. the number of Russian migrants has grown by a factor of 30 in 21 years. This situation places Spain among countries with low rates of Russian native speakers - the Russophone diaspora is not on the list of the biggest immigrant communities given in Alted (2006) - compared to such countries as the USA, Israel and Finland.

It is, however, necessary to consider two factors to understand the size of the presence of Russian in Spain. First, not only immigrants from Russia use the Russian language; many immigrants from other East European and even Asian CIS states are users of Russian as L1 (not to mention those who use it as an L2 for interethnic communication). For this reason, it is difficult to estimate how many Russian-speakers live in Spain, since there is no data on how many immigrants from other CIS countries use Russian in their everyday life. Finally, the official data on immigrants only include those legally established in Spain and do not take into account speakers who reside illegally.

Migration reasons are key social factors in explaining the levels of RHL in Spain. Russian is definitely a heritage language there, if we consider its definition by Scontas, Fuchs \& Polinsky (2015) as a language spoken uniquely at home, whereas the community itself speaks another, dominant language, both being learnt since early childhood, either simultaneously or sequentially but with a short time 
difference between them. What makes Russian a heritage language in Spain involves several characteristics defined in literature, such as its local sociolinguistic status and its condition as a minority language, in the sense that it is learnt at home as opposed to in society (Montrul 2016: 15-16).

The opportunity to maintain Russian in Spain is heterogeneous, uneven and, generally, limited. There are several non-official schools of Russian language and culture for immigrants in different parts of Spain, which were created and are led by associations or alliances of ex-pats. Their presence is dominant on the eastern shore and in the large urban areas, where CIS immigrants are concentrated. Thus, families isolated from CIS immigrant centres usually do not have opportunities to provide their children with Russian language instruction outside the family setting. In addition, natural exposure to the Russian language is very limited ${ }^{1}$.

Despite the major reorganisation of language attitudes and preferences in CIS countries, most of the post-Soviet community in Spain still uses Russian as a lingua franca, with many asymmetric bilinguals in the diaspora. For many of them, Russian was a minority language in their native countries, but currently many immigrants use it as the main linguistic means.

Within the community, one of the factors affecting the maintenance of Russian is the practical absence of any other means to communicate with new in-laws: Spanish people, especially those over 40 , are rarely proficient in any other language than Spanish. Many immigrants acquire Spanish so easily and quickly that they decide (only somewhat voluntarily) to become Spanish-speakers, inhibiting the maintenance of Russian. Definitely, this situation creates specific sociolinguistic conditions for the maintenance of RHL in Spain. One of the most outstanding features of this situation is that, although first-generation speakers frequently rely on intense contact with a Russian-speaking network, second-generation speakers usually do not have much exposure to Russian in their everyday social communication.

\section{Methodological considerations}

Language practices are directed by attitudes and ideologies about the social value of languages, and heritage language transmission is a good example of this bottom-up process. Actually, attitudes to languages in contact between minority (heritage) and majority groups, from both the in-group and the out-group, can have an extensive effect on heritage language maintenance and shift (Jenkins 2018).

\footnotetext{
${ }^{1}$ Only three Spanish universities - in Madrid, Granada and Barcelona - offer official degrees in Slavic Philology (Guzmán Tirado 2017), although many university language centres offer courses in Russian for adults, mainly students and teachers. Among Spanish official schools of languages which admit students over 14 years old, only a few offer courses in Russian from level A1 to level B2. The Embassy of the Russian Federation in Madrid runs a comprehensive school offering primary and secondary education that follows Russian language legislation, but the total number of pupils in the last school year was only 88 .
} 
In Estonia and in most parts of Spain (excluding bilingual communities), mixed families with Russian members typically use the majority language Estonian and Spanish, respectively - and Russian. In order to understand language management in intermarriages in both countries, we conducted parallel fieldwork studies aimed at understanding which social factors shape positive and negative attitudes towards the maintenance of RHL. We applied a quantitative approach based on a questionnaire with both closed and open questions, the content of which was similar to standard inquiries in heritage language studies for immigrant parents (see, for example, Nesteruk's (2010) study of East European immigrants in the USA). The originality of our approach consists of applying similar protocols in two different countries, Estonia and Spain, and collecting comparable data from these two sociolinguistic milieus.

In our study, we do not consider gender differences, income or socioeconomic status information. In addition, the complexities connected with the term 'ethnicity' did not permit the collection of data on ethnic origin: we decided to talk about our study participants as self-reported Russian-speakers, or Russophones. These factors may partly bias the results. In the analysis of data proceeding from the fieldwork, we will use De Houwer's (1999) model combining language ideology, use and development: we thus will analyse the relationship between language practices in the home, parents' attitudes towards RHL maintenance and transmission, and perceived proficiency in RHL. Although we admit that a more qualitative approach would provide us with a deeper and more detailed perspective on language attitudes and practices in migrant families, the scope of the present paper is limited to quantitative data on overt attitudes and ideologies.

\subsection{Russian as a heritage language in mixed families in Estonia: the present study in context}

As described above, Russian has had a long history in Estonia and most Russian-speakers are not recent immigrants but have lived in Estonia their whole lives. Studies on the Russian language and culture in Estonia showed that in the last three decades Russian has assumed a new sociolinguistic position because of political changes and changes in the attitudes of Estonian society. Now, Russian has a lower status than Estonian does, and this creates a feeling of belonging to a language minority group among its speakers (Kemppainen et al. 2004). Intermarriages between ethnic Estonians and Russian-speakers are not frequent (Best 2013). However, many opt to live in common law marriages. This is why many mixed families remain invisible or unreachable for research without the use of a strong social network or a skilled implementation of snowball sampling.

In their recent comparative research, Karpava et al. (2018) found that Russianspeaking members of mixed families in Estonia usually had bilingual RussianEstonian language identity, used Estonian at home more than Russian and, importantly, did not always use RHL with their children. They concluded that Estonia did not favour the maintenance of Russian as a minority language because 
of the general negative attitude to Russia, which meant that L1 Russian-speaking parents experienced higher rates of social negativity. As a result, only half of the children from mixed marriages in Estonia spoke and understood Russian, and only a quarter of them could read and write Russian, while most Russian-speaking population felt discriminated against for their language use.

In the present study, the families had children who attended kindergartens and/or schools with Estonian as the language of instruction or were in Estonianlanguage immersion programmes ${ }^{2}$. As the Spanish sample consists of $97 \%$ females, in Estonia a total of 40 Russian-speaking mothers were chosen from those who answered semi-structured questions about their social and sociolinguistic characteristics and open-ended questions regarding language use, transmission and maintenance, as well as attitudes to all of these processes in their families. The average age of the participants was 38 , with $\mathrm{SD}=6.8$; all 40 participants were women who lived in different parts of Estonia, including such bilingual regions as Tallinn and Maardu, and the mainly Russian-speaking north-east. The participants were all born in Estonia. Most families had one or two children of very different ages: from eight months to 25 years old.

The ethnographic approach posed some limitations on the current study, as mainly females were chosen, but the parents were unique individuals and, as such, they often deviated in their "impact beliefs" (De Houwer 1999), which may have influenced RHL transmission. This study lacks statistical representation, as it is based on the ideologies, understandings and attitudes of the female respondents, which, in a practical sense, are difficult to measure.

\subsection{Russian as a heritage language in mixed families in Spain: the present study in context}

As one of the foreign languages, Russian has an added sociolinguistic value in Spain because of its extended use as a lingua franca among ex-pats from different ex-Soviet countries. Very few sociolinguistic studies were conducted on the status of RHL in Spain. Vorobeva and Bel (2017) analysed the relationship between the use of Russian L1 in home settings in trilingual Catalan-Spanish-Russian children of immigrants and found that the proportion of L1 input and use had a direct influence on the proficiency in RHL. Ivanova (2019) conducted a study on the effects of cognitive and affective factors on the subjective RHL proficiency level in second'generation Russophone immigrants in a small town in central Spain and found that positive self-identification and attitudes of Russophone parents directly influenced the level of proficiency in RHL.

${ }^{2}$ It must be added that Estonian education has become increasingly diverse, especially during the past decade, because of the admission of pupils from both Russian-speaking families and Estonian-Russian bilingual families (in addition, children from new immigrant families may enter schools without any or with very little knowledge of Estonian or Russian). These factors contribute to the creation of cultural and linguistic diversity in 21st-century Estonian schools. 
Forty Russian-speaking parents answered 15 questions concerning their social and sociolinguistic characteristics and, in more detail, questions concerning language use, transmission and maintenance, and attitudes to all these processes, in their families. The items included in the questionnaire were aimed at collecting data on family language policy, contextual language maintenance and perceived language proficiency for both first-generation and second-generation speakers. In this respect, the study is similar to previous methodological designs on heritage language management and acquisition in bilingual families (for example, Altman et al. 2013 for Russian-Hebrew bilingual families in Israel).

The average age of participants was 39 , with $\mathrm{SD}=6.97 ; 39$ of the 40 participants were women $(97.5 \%)$; they lived in different parts of Spain, including such bilingual regions as Catalonia, Valencia, the Basque region and the Balearic Isles. Participants had lived an average of 11 years in Spain, though the range was wide: from 2 to 23 years $(S D=5.84)$. Most families had one or two children of very different ages: from six months to 22 years old.

\section{A comparison of Russian as a heritage language transmission in Estonia and Spain}

\subsection{Family language policies in mixed families}

Most mixed families in Spain had only one Russian-speaking parent member: $67.5 \%$ of participants said that their partners had no competence in Russian (some defined it as $A 0$ Russian, imitating the well-known language proficiency CEFR scale with levels from A1 to C2). Such a situation did not apparently impede the application of the one parent-one language family policy, which is considered to be particularly effective for promoting active bilingualism when one language is minority and has little social support (Takeuchi 2006). The rest of the sample was distributed as follows: $15 \%$ of the partners had basic skills in Russian, $7.5 \%$ had intermediate proficiency, and $10 \%$ were native speakers of Russian. In general, these data clearly showed the tendency of the Spanish partners not to learn the language of their Russophone spouses. In contrast, most Russian-speaking spouses declared themselves "coordinate bilinguals" in Russian and Spanish (42.5\% of the participants selected the option I know Russian and Spanish equally well) and "asymmetric bilinguals" with better proficiency in Russian $(55 \%$ selected the option I know Russian better than Spanish). In general, the Russophone immigrants do not find it difficult to learn Spanish (Marcu 2010), even though they do not know a word when they arrive in Spain.

It was quite a challenge to determine who were Russian-speakers and who were Russian-Estonian bilingual speakers based on their linguistic and cultural backgrounds, which we collected throughout the Estonian regions. It was not always easy to establish who did or did not fulfil the criteria. Firstly, all Russianspeaking respondents had quite proficient command of Estonian because they were originally from Estonia, had graduated from the Estonian (higher) educational system, worked or had worked (if at the time of the study they were at home with 
child(ren)) in Estonian language environments and communicated in Estonian both at work and in their daily social lives. Secondly, individuals had their own selfidentifications and often felt that they were more "Russian-speaking Estonians" or "Estonian Russians" than "Russians" or "Russian-speakers". What all families had in common was that Russian was at least one of the heritage languages of the mother. Living in Estonia, these parents did not experience any language barriers when there was a need to be socially involved or politically informed.

We predicted that these backgrounds would both reflect on and influence the attitudes towards RHL maintenance and transmission, significantly determining family language policies. Spanish Russophone spouses are the language bridge in the mixed families, since they learn Spanish and so assure in-family communication. Simultaneously, they maintain their proficiency in Russian as their native language and potentially can transmit it to their children. Actually, dominant language practices within the mixed families confirm this prediction: Russian and Spanish are both substantially present in family communications, but their agents and purposes are different. At the same time in Estonia, mothers have not only Russian as a mother tongue but are Russian-Estonian bilinguals or very advanced in Estonian and the fathers also identify themselves with both Estonian and Russian (to at least some extent). The data obtained from interviews and observation confirm that this leads to spontaneous translanguaging (i.e. use of both Estonian and Russian interchangeably and without any inner conflict) during in-family communication (Karpava et al. 2019, 2021).

As for the language-commitment of the Russophone spouses in Spanish families, $40 \%$ declare that they use Russian with children and $7.5 \%$ state they exclusively used Russian with their children. The other participants either do not specify the language/s they used with their children or clearly say that Russian is not the only language they use with their children. In the first case, accounting for $22.5 \%$, we can only assume that Russian is used in the family settings, but we cannot claim that it is used as the only language with children. In Russian-Spanish families, the one parent-one language policy is the best approach; otherwise, Spanish would definitely hinder the functionality and generation transmission of RHL. Consequently, from the given data we can be sure that only half of the Russophone parents use the one parent-one language policy, while approximately a quarter of the parents use family language policies with various distributions of Russian and Spanish.

In Estonia, Russian is used in $57.5 \%$ of cases and Estonian in $77.5 \%$. This again shows the chosen attitude towards language use: mixed families try to remain bilingual but under the influence of the larger societal process in Estonian-dominant speech communities Estonian is dominant. $65 \%$ of respondents say that they often code-switch at home and $20 \%$ express concern that their children might sometimes consciously or unconsciously refuse to use or avoid using Russian at home. Thus, the reason for using Estonian and Russian languages interchangeably is not only the attempt to include all conversation partners but it could also be motivated by 
children who construct their own language policies and might not find RHL use necessary in their social spheres.

In Spain, with $30 \%$ of speakers, language combinations are different. First, some Russophones tend to mostly use Russian with their children, but shift to Spanish when Spanish-speaking relatives (e.g. their spouse or parents-in-law) are present. This group also emphasises their intention to mainly use Russian: "I try to speak Russian to my child", but "I do not always succeed in it". However, a group of Russian-speaking parents state they use Russian, Spanish and other languages present in their highly mixed families, e.g. English, Georgian, Catalan or Ukrainian, as common communicative tools. The speakers themselves define their family language situations as "language blends" and different languages are used "all mixed when talking to everybody." In Estonia, only 5\% (two mothers) claim to use Russian-only purposely with their children at home. This might be a result of schoolteachers' or other educators' attitudes towards bilingual language use, which is often seen as causing gaps in lexicon, morphosyntax or "ideal" pronunciation. When a bilingual child enters an Estonian-medium kindergarten or school, in order to measure his/her language abilities and practices, monolingual children are used for comparison. One of the mothers gave an example of a seven-year-old daughter: "when she said about a cat: "see on kisa" "this is a cat', then a speech therapist predicted complete backwardness in the future and recommended she forget Russian completely." In Estonian, a cat is kass and a kitten is kiisu, while in Russian a cat is koshka and kisa is its diminutive. In other words, kisa is a mixture of the Estonian and Russian words for kitten. A sociolinguist might speculate about the code-switched word being a result of a possible phonological facilitation but for the therapist it was just a deviation from a norm that had to be removed as an abnormality. This reaction exemplifies a typical Herderian philosophy towards language and language use interpretation that is supported by Estonia's teachers, speech therapists, etc.: it was not only at the end of the 1990s/beginning of the 2000s when bilingual families were recommended not to use Russian at home because of "its harmful influence on development of real Estonian," but it is also a very common attitude nowadays. There are also numerous examples given by mothers in which "a kindergarten teacher says that if your child starts/continues speaking Russian, then the whole kindergarten will switch to Russian. So please do not show other children that your family is Russian-speaking." Besides these "horror stories" there are also examples in which "there is a boy in this kindergarten, coming from a fully Russian family whose parents speak poor Estonian and who has to learn Estonian and become a real Estonian speaker."

In essence, Russian-Spanish families in Spain and Russian-Estonian families in Estonia vary greatly in their commitments to the transmission of RHL. In Spain, only half of all Russophone parents use a Russian-only communicative strategy with their children and about a third of Russophone parents admit not using Russian solely when communicating with children. In Estonia, there were no families where both parents opted for Russian-only, and only two mothers try to implement a one 
parent-one language strategy, using Russian only. A possible explanation is that Russian-speaking immigrants use Spanish as a means to achieve a deeper integration into their host society: according to a qualitative study by Marcu (2010), many East European immigrants feel they play a secondary role in the Spanish society. Their speaking Spanish, thus, may be a tactic, either conscious or unconscious, to achieve deeper integration. In Estonia, a feeling of being a secondclass citizen if you do not speak Estonian at a nearly native level also prevails; consequently, speaking Estonian facilitates children's connection with mainstream schools and builds strong bridges with the dominant society and culture.

\subsection{Attitudes to the maintenance and transmission of Russian as heritage language}

When asked about their language attitudes, Russophones from intermarriages in Spain were positive about Russian language maintenance with their children: more than $90 \%$ believe their children should know Russian as heritage language. The increasing demand for Russian in the job market both in Estonia and in the EU pushed Russian-Estonian bilingual families close to a $100 \%$ positive attitude towards RHL transmission.

However, despite this general positive attitude to RHL, beliefs about why Russian is important for the younger generation vary. In Estonia, Russian is gradually losing ground to Estonian in education, which is evident in the choice of the language of instruction in kindergarten, school and hobby schools, although among those families Russian is still considered important as a language of a "great people", "great culture", "unique Russian soul" and a "language of world classics." In Spain, there is a belief that Russian is necessary for its affective link because it is a native language of the children $(22.5 \%)$ and is, thus, part of their identification, their "roots" and cultural traditions. Overall, affective reasons are not dominant: they are given by only $37.5 \%$ of the parents. In Estonia, parents support their children feeling "both Russian and Estonian" $(62.5 \%)$, or "Estonian but still having Russian roots" (37.5\%). Notably, participants criticise those bilingual families who "try to raise Estonians-only" because this creates in their children a "disturbing identity." where they are in constant search of themselves: "I saw one example where a girl could not find a place for herself among Estonians ... no matter how hard she tried she still could not erase her Russian soul. I believe that my child will not be negatively affected but instead will be proud of the mastery of the great Russian language and culture."

Spanish respondents give much more weight to functional reasons. As one of the major languages of the world, Russian could potentially offer job and educational opportunities to immigrants' children, since it "gives additional benefits" (30\%). Furthermore, knowing Russian is important for maintaining contact and communication with relatives and the country of origin (32.5\%). In fact, this position is pragmatic: Russian is one of the most commonly used languages worldwide and in many post-Soviet diasporas it is the lingua franca used by 
speakers of very different nationalities. This position is expressed by Russophone parents of transnational families in Spain, who state that knowing an additional language (i.e. Russian) is important since "languages are not superfluous" $(15 \%)$. In this context, Russian is seen as an "additional language" $(10 \%)$, on a par with other important languages, such as English. In Estonia, claims that "many jobs here require Russian, not only Estonian" (80\%) and "it is good to speak many languages" $(90 \%)$ are more common than "Russian will increase the opportunity to study in Russia and have a greater variety of professions" $(5 \%)$. Also, according to this study, Estonia's mixed families do not name the necessity to communicate with Russian-speaking relatives in Russia and seem unworried about communication with Russian-speaking family members living in Estonia, as children would pick up the language naturally from the environment even if a family lived in an Estonian-dominant region: "we send our son to Narva [a town on the Russian border with an almost $90 \%$ ethnic Russian population] every holiday and on other occasions to stay with my parents, to interact with them, inside the environment." At the same time, the role of grandparents in teaching or speaking in Russian in early childhood is mentioned by $70 \%$ : "our grandmother speaks Russian only and this is how our child acquired it without obvious difficulty." In this respect, previous research (for example, Moustaoui 2020) already reported the grandparent factor in heritage language maintenance.

There is a third group of reasons for positive attitudes towards RHL transmission in mixed families in Spain: personal development. Although the percentage is not very high, a group of parents say that Russian is what their children "need for their own development" (20\%). A very small number of parents mention aesthetic motivation: enriching a person's interior world (5\%), being bilingual (5\%) and being able to read impressive literature in its original language (2.5\%). A significant difference with the Spanish data is that Russian in Estonia is viewed as a link to higher culture and a prestigious cultural background that is not available to non-speakers of Russian (100\%): "my child will not read Lermontov in a clumsy translation" or "Pushkin's fairy tales are not 'Spring and a piece of shit' [a popular children's book written by an Estonian writer]". This is the main point when Estonian is (sometimes too heavily) criticised because of its weak and poor cultural connections. The paradox is that the same parents send their children to Estonian-medium schools because it is the language "that people use with one another" here, "needed for profession," or "an indication of education" but they feel that only Russian culture might form a child into a fully cultured person (Table 1).

In Spain, these reasons reveal the pragmatic approach of Russophone parents to RHL transmission: Russian is above all considered to be a useful communicative means that might improve their children's job prospects, and its affective value is seen as being relatively unimportant. In Estonia, the positive attitude towards RHL transmission motivated by the great heritage culture and identity-related considerations were well documented previously (Karpava et al. 2020) and are totally confirmed in this study. 
Table 1

Reasons declared for transmitting RHL to their children

\begin{tabular}{|l|c|c|}
\hline Reasons declared by Russophone parents from mixed families & Spain & Estonia \\
\hline It allows them to stay in contact with relatives & $32.5 \%$ & $0 \%$ \\
\hline It may provide job and educational opportunities & $30 \%$ & $80 \%$ \\
\hline It is their native language & $22.5 \%$ & $37.5 \%$ \\
\hline It enhances personal development & $20 \%$ & $100 \%$ \\
\hline It is an additional language to know & $10 \%$ & $90 \%$ \\
\hline It represents their roots and culture & $10 \%$ & $37.5 \%$ \\
\hline It enriches a person's interior world & $5 \%$ & $100 \%$ \\
\hline It allows one to be bilingual & $5 \%$ & $62.5 \%$ \\
\hline It allows one to read literature in the original language & $2.5 \%$ & $100 \%$ \\
\hline
\end{tabular}

\subsection{Assessed language proficiency in Russian as a heritage language in the second generation}

The overwhelming majority of Russophone parents from intermarriages in Spain $(90 \%)$ and all Russian-speaking parents in Estonia (100\%) want their children to have native-level proficiency in Russian. The parents say that it is a sine qua non prerequisite for their children to feel they are also Russian, to freely interact with all their family, to be more tolerant of other ethnic groups and nations, and to get a head start on learning other foreign languages. In both countries, the parents appear to be very aware of the need for RHL; however, there are variations in the parents' motivations and expectations.

When asked about the language proficiency of their children, only $34 \%$ of parents in Spain state that their children are fully balanced Spanish-Russian bilinguals. Of these parents, about half use the one parent-one language policy at home and thus only speak Russian with their children; the other half use both Russian and Spanish, though most of them state that the proportion of Spanish in these communicative practices is small. In describing their children's language competence in detail, parents state that their grammar mistakes are typical of the developmental stages associated with the children's ages, and the most common "deviation" from Russian native fluency is a slight accent. They stress that everything is normal with the proficiency in Russian in their children, who "are not different from children living in Russia." Parents state that their children use Russian freely in any context, in general, "in any (situations) where she knows that she will be understood." In terms of fully balanced bilingualism, 50\% of RussianEstonian families state that, despite their desire to succeed, they are bitterly disappointed in the results (which might vary even among children in the same family): "the older one is equally proficient, as there are no problems at all with one or another language, and the youngest is... with her it has not worked out." This may also have been reflected in the overall view of respondents who intuitively feel that their children's Russian was somewhat different from the Russian of children in Russia "because after all, two languages have intertwined." 
$40 \%$ of parents in Spain declare that their children are unbalanced bilinguals, whose knowledge of Russian is worse than that of Spanish; the same was true of $50 \%$ of Estonian-Russian families who make a conscious effort to teach their children Russian as it is "important because of its rich cultural roots." In Spain, half of the parents also use the one parent-one language policy, which confirms previous observations (e.g. Takeuchi 2006) that this family language strategy is not sufficient to assure native-level proficiency in the heritage language. Some parents from this group attribute general worse proficiency in Russian to their children: "she of course (speaks) worse in Russian" in comparison with Spanish because of the language environment they lived in. "Of course they speak better in Spanish, but it is just because they live in Spain. If they lived in Russia, they would surely speak better in Russian." Parents in this group also try to excuse their children's lack of balanced bilingualism. For example, they emphasise the important meta-bilingual competence of their children: "For children, Russian is not the main language in the family, but they try their best. They never mix them up; they address each of the parents in their 'own' language." In Estonia, the respondents reported that the main problem was "kitchen" Russian and "of course we're not satisfied but all parents can always find flaws and here patience and motivation matter a lot; this is how they can inspire their child and this is what I do." On the other hand, one Russianspeaking mother says: "If she does not know how to say something in Russian, then she asks "miks...kat eto skazat" (Est "why'... Rus 'how to say that') and continues in Estonian. It is very funny, it is very... I think it is cool, that everything is fine" ("То есть это очень забавно, это очень ... я считаю здо́рово, то есть всё нормально"). The pedagogical implication of such an attitude shown by a Russianspeaking mother cannot be underestimated: providing such an answer full of optimism ("funny-cool-fine") for code-switching cannot be taken as a means of promoting RHL use by her child.

Special attention is warranted by the third group of parents in Spain, who define their children as trilinguals for whom Russian is the third language (there is no similar group in the Estonian data set). This normally occurs in families living in bilingual parts of Spain, e.g. Catalonia, where Catalan is the first language children learn, followed by Spanish and only then by Russian (13\%): "in my case, Russian is their third language, after Catalan and Spanish." In some other cases, Russian is the third most-known language because parents encourage the knowledge of English over Russian (10\%). Among these families, only $28 \%$ use the one parent-one language policy, while the rest use Russian and Spanish, as well as other languages, e.g. Catalan and English, in communicating with their children, which is consistent with other studies suggesting that parents' attitudes and ideologies do not necessarily match actual language practices at home. As a result, proficiency in RHL is limited: the children "understand but hardly speak Russian" or (the child) "understands Russian but does not speak it at all." The following statement summarises language proficiency in such families: "My children indeed speak Spanish best, then English and only after that Russian." 
Figure 1 shows the relationship between family language policy and assessed language proficiency in RHL in the second generation in Spain. There were two tendencies: assessed balanced and unbalanced bilingualism may have arisen with equal probability from both the one parent-one language strategy and mixed Russian-Spanish communication from the Russophone parent. This observation is in line with previous studies, e.g. Isurin \& Ivanova-Sullivan (2008), who defined RHL speakers in the USA as "lost in between" in the continuum of language speakers: they could not be considered as speakers of an L2/FL, but they usually fell below native speakers in some grammatical respects. On the other hand, trilingualism and multilingualism in the family tend to move Russian into the position of the third family language, with direct impact on second generation proficiency in RHL.

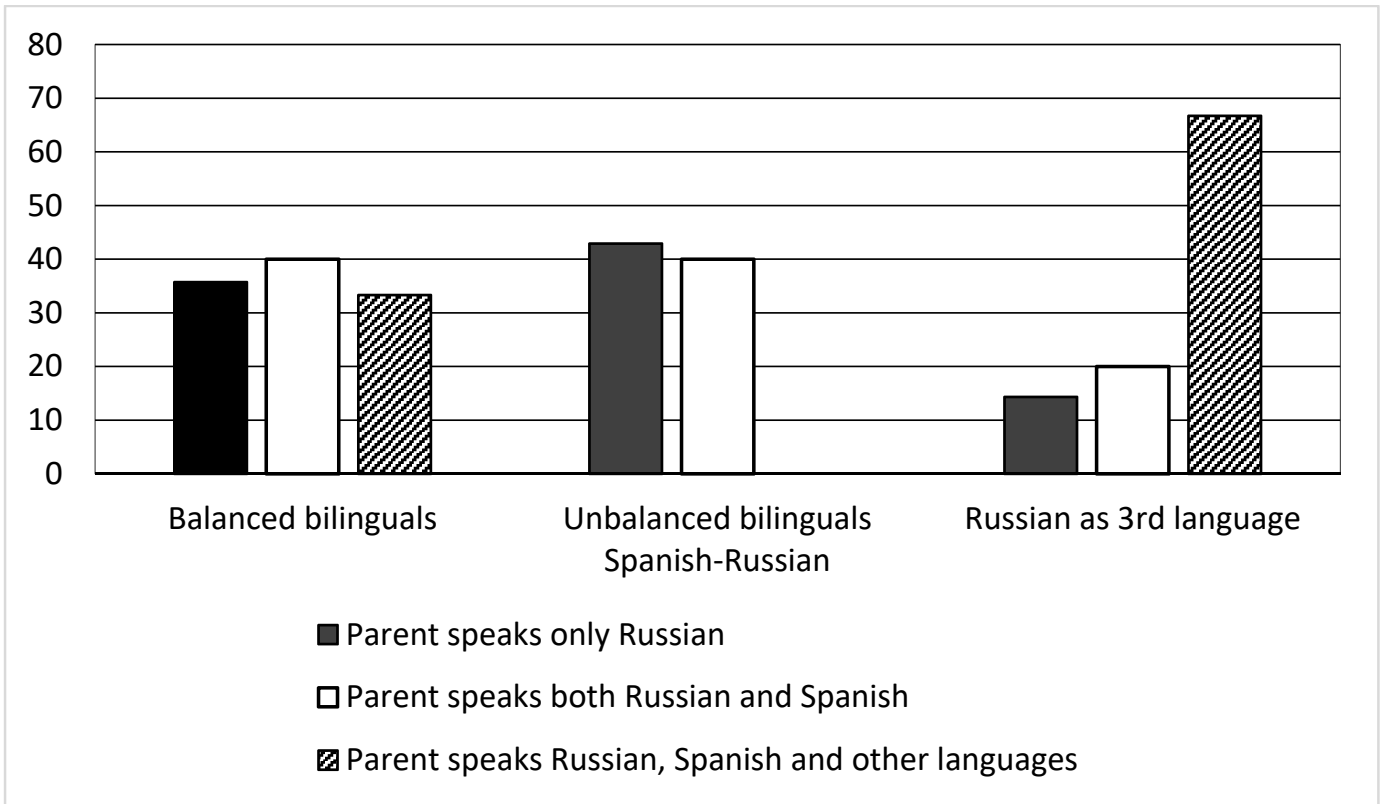

Figure 1. Family language policy and assessed RHL proficiency in the second generation

\section{Concluding comments}

With immigrant Russians, it is assumed that speakers accept or reject maintaining and transmitting RHL in accordance with their attitudes to the country of origin and its international policies (Mustajoki et al. 2020). This paper presents comparative results from ethnographic research conducted in different parts of Estonia and Spain, and thus offers important information about sociolinguistic variation in RHL maintenance and loss. It provides evidence of how different sociolinguistic backgrounds and social milieux may affect all processes related to RHL transmission: management, maintenance, use and proficiency.

In Spain, these factors form specific sociolinguistic profiles, which may foster the maintenance of Russian in mixed families, leave it in an intermediate position 
(Russian is not "banned" in the families but is not specifically maintained), or hinder its position as a heritage language. Mixed Russian-Spanish families may thus be classified into three groups: 1) families with fully-bilingual children, 2) families with asymmetric bilingual children and 3) families with Spanish monolingual children. In line with previous research (cf. Schwarz 2008), the fieldwork with Spanish Russophones reveals that family language policy in diaspora is inconsistent. Of course, socioeconomic background explains gradual variation in RHL maintenance in intermarriages in Spain. Such factors were described by Jenkins (2018), based on multiple previous sociolinguistic studies of heritage languages, as those responsible for linguistic assimilation of immigrant groups and determinant in heritage language maintenance or shift.

Although it is true that studies on heritage language transmission and maintenance point in the "wrong" direction (cf. Nesteruk 2010) - the number of balanced bilinguals in the second generation is low and most children gradually lose (if they have previously acquired) their heritage language in favour of the dominant language of the country - in Spain the situation does not seem to be very severe. Indeed, heritage speakers usually show attainment in their heritage language and do not necessarily feel they have to achieve native-like proficiency in the heritage language (Scontas et al. 2015). This may not be due to family language planning, but rather to the overall bilingual family language policy towards the maintenance of RHL.

In Estonia, the situation of RHL transmission involves paradoxes: none of the study participants consider RHL unnecessary, and each provides a list of the best aspects of RHL and maintaining Russian cultural identity in the child, but they are not successful in spite of their strong motivations and high expectations in terms of the children's competence ("in reading Russian classics"). They are actually increasing RHL loss because their children actively employ code-switching to compensate for imperfect knowledge to get high-level education in Estonian, while picking up Russian from the natural environment, which is certainly not enough to facilitate satisfactory outcomes. Clearly, this situation shows that Russian-speaking parents must be patient and supportive in teaching their children to use Russian well and to encourage them not to lose interest in RHL: this could be done by making the child aware from early childhood that language learning is a conscious mental process and one has to practice and expand RHL constantly. In both Estonia and Spain, there is a significant number of Russian-speaking parents committed to RHL transmission and strongly convinced of the importance of Russian, both as an international and as a native language that might improve their children's job prospects. At the same time, the status of RHL at the individual family level is conditioned by constantly negotiating clashing social, sociolinguistic, psycholinguistic and political factors.

We would like to finish by highlighting the most important implications of our research. First, we could confirm that the maintenance of RHL is driven by both affective and functional factors, what singles out Russian among other heritage 
languages in European countries: Russophones believe that Russian is not only important for its commodification value, but also for its associated cultural heritage. Second, we could observe that even small, unsupported communities tend to maintain RHL, although at a relatively modest level. Russophone communities in Spain and Estonia are highly variable in their attitudes to RHL maintenance, but still, in most families, the tendency is to favour Russian. Finally yet importantly, our research confirms the extreme importance to promote external additional education for supporting heritage languages proficiency in successive generations.

(C) Olga Ivanova and Anastassia Zabrodskaja, 2021 cc)creative

This work is licensed under a Creative Commons Attribution 4.0 International License https://creativecommons.org/licenses/by/4.0/

\section{Author contributions}

Authors 1 and 2 contributed equally and should be considered co-first authors.

\section{Acknowledgements}

This article was supported by basic funding for research areas of national significance at the Institute of Estonian and General Linguistics of the University of Tartu. The theoretical results are part of the project IUT20-3 "Sustainability of Estonian in the era of globalisation" (EKKAM).

\section{REFERENCES}

Adamson, Inna \& Natalia Tshuikina. 2015. The Russian language in Estonia: Between politics and pragmatism. Russian Journal of Communication 7 (2). 208-213.

Alted, Alicia. 2006. España, de país emigrante a país de inmigración. In Alicia Alted \& Almudena Asenjo (eds.), De la España que Emigra a la España que Acoge, 30-57. Madrid: Fundación Francisco Largo Caballero.

Altman, Carmit, Zhanna Burstein Feldman, Dafna Yitzhaki, Sharon Armon Lotem \& Joel Walters. 2013. Family language policies, reported language use and proficiency in Russian-Hebrew bilingual children in Israel. Journal of Multilingual and Multicultural Development 35 (3). 216-234.

Aref'ev, Alexander Leonardovich. 2014. The Russian language in the world: Past, present, and future. Herald of the Russian Academy of Sciences 84 (5). 357-364.

Babiano, José \& Sebastián Farré. 2002. La emigración española a Europa durante los años sesenta: Francia y Suiza como países de acogida. Historia Social 42. 81-98.

Best, Marina. 2013. The ethnic Russian minority: A problematic issue in the Baltic states. Verges: Germanic and Slavic Studies in Review 2 (1). 33-41.

Branchadell, Albert. 2011. Assessing language policy. The treatment of Russian in Estonia and Spanish in Catalonia. Revista de Llengua i Dret 55. 123-150.

Corkill, David. 2001. Economic migrants and labour market in Spain and Portugal. Ethnic and Racial Studies 24 (5). 828-844. 
De Houwer, Annick. 1999. Environmental factors in early bilingual development: The role of parental beliefs and attitudes. In Guus Extra \& Ludo Verhoeven (eds.), Bilingualism and Migration, 75-96. New York: Mouton de Gruyter.

Denisenko, Mikhail. 2020. Emigration from the CIS Countries: Old Intentions - New Regularities. In Mikhail Denisenko, Salvatore Strozza \& Matthew Light (eds.), Migration from the Newly Independent States. 25 Years after the Collapse of the USSR, 81-126. Cham: Springer.

Ehala, Martin, and Anastassia Zabrodskaja. 2013. Ethnolinguistic vitality of ethnic groups in the Baltic countries. In Sarah Smyth \& Conny Opitz (eds.), Negotiating Linguistic, Cultural and Social Identities in the Post-Soviet World, 45-85. Oxford, Bern, Berlin, Bruxelles, Frankfurt am Main, New York, Wien: Peter Lang Verlag.

García, MaryEllen. 2003. Recent research on language maintenance. Annual Review of Applied Linguistics 23. 22-43.

Guzmán Tirado, Rafael. 2017. About Russian language in Spain and in the University of Granada. Русский язык за рубежом. Специальный выпуск: Русистика Испании. (In Russ.)

Hirsch, Tijana \& Jin Sook Lee. 2018. Understanding the complexities of transnational family language policy. Journal of Multilingual and Multicultural Development 39 (2). 882-894.

Isurin, Ludmila \& Tanya Ivanova-Sullivan. 2008. Lost in between: The case of Russian heritage speakers. Heritage Language Journal 6 (1). 72-104.

Ivanova, Olga. 2019. 'My child is a perfect bilingual': Cognition, emotions, and affectivity in heritage language transmission. Languages 4 (2). 44.

Jenkins, Devin. 2018. Spanish language use, maintenance, and shift in the United States. In Kim Potowski \& Javier Muñoz-Basols (eds.), The Routledge Handbook of Spanish as a Heritage Language, 53-65. Abingdon / New York: Routledge.

Karpava, Sviatlana, Natalia Ringblom \& Anastassia Zabrodskaja. 2018. Language ecology in Cyprus, Sweden and Estonia: Bilingual Russian-speaking families in multicultural settings. Journal of the European Second Language Association 2. 107-117.

Karpava, Sviatlana, Natalia Ringblom \& Anastassia Zabrodskaja. 2019. Translanguaging in the family context: Evidence from Cyprus, Sweden and Estonia. Russian Journal of Linguistics 23 (3). 619-641.

Karpava, Sviatlana, Natalia Ringblom \& Anastassia Zabrodskaja. 2020. Family language policy leading to multilingual home literacy environment: Evidence from interviews with Russian-speaking mothers in Cyprus, Estonia and Sweden. HumaNetten 45. 11-39.

Karpava, Sviatlana, Natalia Ringblom \& Anastassia Zabrodskaja. 2021. Translanguaging space and translanguaging practices in multilingual Russian-speaking families. Russian Journal of Linguistics 25 (4). 931-957.

Kemppainen, Raija, Scott E. Ferrin, Carol J. Ward \& Julie M. Hite. 2004. "One should not forget one's mother tongue": Russian-speaking parents' choice of language of instruction in Estonia. Bilingual Research Journal 28 (2). 207-229.

King, Kendall A., Lyn Fogle \& Aubrey Logan-Terry. 2008. Family language policy. Language and Linguistics Compass 2 (5). 907-922.

Laitin, David D. 1992. Language normalization in Estonia and Catalonia. Journal of Baltic Studies 2. 149-166.

Lanza, Elizabeth. 2007. Multilingualism and the family. In Peter Auer \& Li Wei (eds.), Handbook of Multilingualism and Multilingual Communication, 45-66. Berlin: De Gruyter.

Leifsen, Esben \& Alexander Tymczuk. 2012. Care at a distance: Ukrainian and Ecuadorian transnational parenthood from Spain. Journal of Ethnic and Migration Studies 38 (2). 219-236. 
Marcu, Silvia. 2010. Fronteras de cristal de la inmigración. Visión de los inmigrantes del Este Europeo en España. ARBOR. Ciencia, Pensamiento y Cultura 744. 721-736.

Maximova, Svetlana, Oksana Noyanzina, Daria Omelchenko \& Margarita Maximova. 2018. The Russian-speakers in the CIS countries: Migration activity and preservation of the Russian language. MATEC Web of Conferences 212. 1-11.

Montrul, Silvina. 2016. The Acquisition of Heritage Languages. Cambridge: Cambridge University Press.

Moustaoui, Adil. 2020. Making children multilingual: Language policy and parental agency in transnational and multilingual Moroccan families in Spain. Journal of Multilingual and Multicultural Development 41 (1). 108-120.

Mustajoki, Arto, Ekaterina Protassova \& Maria Yelenevskaya. 2020. The Russian language away from the Metropolis: Challenges of pluricentric development. In Arto Mustajoki, Ekaterina Protassova \& Maria Yelenevskaya (eds.), The Soft Power of the Russian Language. Pluricentricity, Politics and Policies, 3-12. London/New York: Routledge.

Muth, Sebastian (ed.). 2017. Commodification of Russian. [Special issue]. Russian Journal of Linguistics 21 (3).

Nesteruk, Olena. 2010. Heritage language maintenance and loss among the children of Eastern European immigrants in the USA. Journal of Multilingual and Multicultural Development 31 (3). 271-286.

Pavlenko, Aneta. 2006. Russian as a lingua franca. Annual Review of Applied Linguistics 26. 78-99.

Pavlenko, Aneta (ed.). 2008. Multilingualism in post-Soviet countries. [Special issue]. International Journal of Bilingual Education and Bilingualism 11 (3-4).

Pavlenko, Aneta. 2013. Multilingualism in Post-Soviet successor states. Language and Linguistics Compass 7 (4). 262-271.

Pencheva, Antonia. 2017. RETOUR - An Innovative Russian Language Training Resourse for Tourism Workers in the EU. Russian Journal of Linguistics 21 (3). 635-652.

Pillai, Stefanie, Wen-Yi Soh \& Angela S. Kajita. 2014. Family language policy and heritage language maintenance of Malacca Portuguese Creole. Language \& Communication 37. $75-85$.

Ryazanova-Clarke, Lara (ed.). 2014. The Russian Language outside the Nation. Edinburgh: Edinburgh University Press.

Schwarz, Mila. 2008. Exploring the relationship between family language policy and heritage language knowledge among second generation Russian-Jewish immigrants in Israel. Journal of Multilingual and Multicultural Development 29 (5). 400-418.

Scontas, Gregory, Zuzanna Fuchs \& Maria Polinsky. 2015. Heritage language and linguistic theory. Frontiers in Psychology 6. 1545.

Siiner, Maarja. 2006. Planning language practice: A sociolinguistic analysis of language policy in post-communist Estonia. Language Policy 5. 161-186.

Spanish National Institute for Statistics. URL: www.ine.es (accessed 14 November 2021).

Spolsky, Bernard. 2012. Family language policy: The critical domain. Journal of Multilingual and Multicultural Development 33 (1). 3-11.

Suryanarayan, Neelakshi. 2017. The role of the Russian language in India's healthcare sector. Russian Journal of Linguistics 21 (3). 515-529.

Takeuchi, Masae. 2006. Raising Children Bilingually through the 'One Parent-One Language' Approach. A Case Study of Japanese Mothers in the Australian Context. Bern et al.: Peter Lang.

Verschik, Anna. 2005. The language situation in Estonia. Journal of Baltic Studies 36. 283-316. 
Vorobeva, Tamara \& Aurora Bel. 2017. Factors affecting language proficiency in heritage language: The case of Young Russian heritage speakers in Spain (conference paper). $11^{\text {th }}$ International Symposium on Bilingualism, University of Limerick.

\section{Article history:}

Received: 20 May 2021

Accepted: 20 October 2021

\section{Bionotes:}

Olga IVANOVA is Associate Professor of General Linguistics at the Spanish Language Department of the University of Salamanca, Spain. Her primary research interest is language development during the lifespan, with particular focus on heritage language acquisition and bilingualism and language impairment in old age and dementia. She is a member of the research group "Neurophysiology, Cognition and Behaviour" of CastileLeon Institute of Neurosciences and of the research group "Aging and Dependency Prevention" of the Institute for Biomedical Research, both in Spain. She is the founder and president of the Association for Russian as Heritage Language in Salamanca, Spain.

\section{Contact information:}

University of Salamanca

Plaza de Anaya s/n, 37008 Salamanca, Spain

e-mail: olga.ivanova@usal.es

ORCID: 0000-0002-9657-5380

Anastassia ZABRODSKAJA (PhD) is Professor of Intercultural Communication and Head of the Communication Management Master's programme at Tallinn University. She is in charge of the management of the European Master's in Intercultural Communication programme. Her primary research interests are identity, language contacts and linguistic landscape. She is a Regional Representative (Europe) on the Executive Committee of International Association of Language and Social Psychology and a Management Committee Member of the European Family Support Network COST Action: A bottomup, evidence-based and multidisciplinary approach.

\section{Contact information:}

Tallinn University

Baltic Film, Media and Arts School

Narva mnt 27, 10120 Tallinn, Estonia

e-mail: anastassia.zabrodskaja@gmail.com

ORCID: 0000-0001-8082-3549

\section{Сведения об авторах:}

Ольга ИВАНОВА - доцент кафедры испанского языка университета Саламанки, Испания. Сфера ее научных интересов - эволюция владения языком в течение жизни, в особенности при владении эритажными языками и двуязычием, а также изменения в языковом владении в пожилом возрасте. Является научным сотрудником исследовательской группы «Нейрофизиология, познание и поведение» в Институте нейронаук Кастильи и Леона, а также рабочей группы «Старение и профилактика зависимости» в Институте биомедицинских исследований (Испания). Основатель и президент Ассоциации русского языка как эритажного в Саламанке (Испания). 


\section{Контактная информация:}

University of Salamanca

Plaza de Anaya s/n, 37008 Salamanca, Spain

e-mail: olga.ivanova@usal.es

ORCID: 0000-0002-9657-5380

Анастасия ЗАБРОДСКАЯ (PhD) - профессор межкультурной коммуникации Таллинского университета, руководитель магистерской программы «Управление коммуникацией». Она также руководит программой Европейской магистратуры по межкультурной коммуникации. Сферу ее научных интересов составляют идентичность, языковые контакты и языковой ландшафт. Она является региональным представителем Европы в Исполнительном комитете Международной ассоциации языков и социальной психологии и членом Межправительственной структуры по координации национальных исследований на европейском уровне по вопросам многоязычной семьи.

\section{Контактная информация:}

Tallinn University

Baltic Film, Media and Arts School

Narva mnt 27, 10120 Tallinn, Estonia

e-mail: anastassia.zabrodskaja@gmail.com

ORCID: 0000-0001-8082-3549 